\title{
Glukóz- és zsíranyagcsere terhességben
}

\author{
Rácz Olivér dr., ${ }^{(1,2)}$ Brenisin Marek dr., ${ }^{(1)}$ Maceková Denisa ${ }^{(1)}$
}

\begin{abstract}
Osszefoglalás
A szerzök ismertetik a glukóz- és a zsiranyagcsere változásait anyagcserezavarral nem társuló terhességben, valamint gestatiós diabetesben és preeclampsiában. Rámutatnak arra, hogy a terhesség alatti laboratóriumi referenciaadatok hiányosakés nem egyeznek a kóros állapotok diagnózisában alkalmazott határértékekkel sem. A glukóz-és a lipidanyagcsere terhesség alatti változásainak középpontjában az inzulinrezisztencia áll, amely ebben az esetben nem kóros folyamat, hanem a fokozatosan növekvö magzati igényekre bekövetkezö kompenzációs válasz. Külön fejezetben tárgyalják az adipokinek szerepét a terhességi anyagcsere-folyamatokban. Feltételezik, hogy a gestatiós diabetes patogenezisét tekintve nem egységes kórkép, és rámutatnak arra is, hogy a preeclampsia patogenezisében is fontos szerepet játszik az inzulinrezisztencia. Az irodalmi áttekintést javaslatok zárják a megválaszolatlan kérdések lehetséges megoldásaira.
\end{abstract}

Kulcsszavak: terhesség, anyagcsere, inzulinrezisztencia, gestatiós diabetes, preeclampsia

\section{Glucose- and lipid metabolism during pregnancy}

Summary: Modifications of glucose and lipid metabolism during pregnancy not accompanied by metabolic disturbances, as well as in gestational diabetes and preclampsy are discussed in the review article. Deficient laboratory reference values in normal pregnancy and alterations from those observed in different pathologic conditions are emphasized by the authors. The insulin resistance which is the key element of metabolic regulation during pregnancy is not a pathological process but a physiological adaptation, a compensatory response of the maternal organism to increasing fetal metabolic needs. The role of different adipokines in normal pregnancy as well as in gestational diabetes is also discussed in detail. From pathogenetic point of view the gestational diabetes is not a unified disease. Possibilities for future investigations to clarify the still open questions and suggestions of the authors are also summarised.

Key words: pregnancy, metabolism, insulin resistance, gestational diabetes, preeclampsy

DIABETOLOGIA HUNGARICA 25 (№3) 167-174. 2017. április

DOI: $10.24121 / \mathrm{dh} .2017 .11$

\section{Rövidítések}

APO: apolipoprotein; Arcp30: szabályozó fehérje (adipocyte complement related protein); BMI: testtömegindex (body mass index); GDM: gestatiós diabetes; HAPO: a terhesség alatt felismert emelkedett vércukorszint és a terhességi kimenetel összefüggését vizsgáló tanulmány (Hyperglycemia and Adverse Pregnancy Outcomes); HOMA (IR): az inzulinhatást jellemzö modellszám (homeostasis model assessment); QUICKI: az inzulinhatás jellemzésére használt mutató (quantitative insulin-sensitivity check index); RBP-4: retinolkötỏ fehérje (retinol binding protein)-4; SPARC: az oszteonektin szabályozó fehérje új elnevezése (secre-ted acidic protein rich in cystein)

A terhesség csodálatos és rendkívül bonyolult élettani folyamat. Feladata a megtermékenyített petesejtből, két genom egyesülése után bebiztosítani a következő nemzedék egyéneinek fejlődését addig az időpontig, amíg képessé válnak az anyaméhen kívüli életre.
A terhesség folyamán bekövetkező anyagcsere-folyamatok első megközelítésben viszonylag egyszerűen jellemezhetők: az anya szervezete mindent megtesz a fejlődő magzat követelményeinek biztosítására anélkül, hogy ez a saját anyagcseréje integritását veszélyeztetné. Amennyiben túllépünk ezen a szinten és megpróbáljuk megérteni azokat 
az okokat és folyamatokat, amelyek a terhességi anyagcserezavarok mögött állnak, már nem eléggé tiszta a kép és hiányos a tudásunk is. A nehézségek hátterében az áll, hogy a terhesség alatt három szabályozó rendszer dinamikus integrációjára van szükség - az anyai és a magzati szervezet mellett a harmadik a placenta -, amelyeknek az ismert feladataik (oxigén, tápanyagok transzportja, a salakanyagok eltávolítása) mellett intenzív humorális regulációs szerepe is van.

Ebben az áttekintő munkában a terhességi cukor- és zsíranyagcsere kérdéseire szeretnénk összpontosítani, különös tekintettel két gyakori kórkép, a gestatiós diabetes (GDM) és a preeclampsia patogenezisére.

\section{Laboratóriumi értékek, és ami mögöttük van}

A terhesség élettana jól ismert. Ugyanez nem mondható el a terhességben mért laboratóriumi biokémiai értékekről, az úgynevezett referenciatartományokról. Ennek az oka nyilvánvaló. A terhesség csak a népesség egyik felére és életkorban viszonylag rövid időszakra korlátozódik, ugyanakkor dinamikus folyamat. Lehet és kell is vitatkozni azon, hogy mennyiben azonosak a referencia-tartományok a szokásos „normális” (fiziológiás) értékekkel, de a mindennapi gyakorlatban ezek nélkül nem lehet megítélni kóros állapotok fennállását vagy hiányát, azaz nem lehet diagnózist felállítani. Ez leginkább azokra a kórképekre érvényes, amelyeknek nincs feltűnő klinikai szimptomatológiájuk (pl. a GDM), vagy laboratóriumi adat, ami része a diagnosztikai algoritmusnak (pl. a proteinuria preeclampsiában).

A vércukorra és a plazmalipidekre vonatkozó értékeket az 1. és 2. táblázat tartalmazza. A lipidek referenciaértékeire vonatkozó bizonytalanságokat jól mutatja Gallos és munkatársai metaanalízise, ${ }^{1}$ amelyben a hypertriglyceridaemia és a preeclampsia közötti összefüggést vizsgálták. A 28

\section{1. táblázat. Vércukor és lipidek referenciaértékei terhességben²}

\begin{tabular}{|c|c|c|c|}
\hline & 1. trimeszter & 2. trimeszter & 3. trimeszter \\
\hline Éhomi vércukor, mmol/l & nincs adat & $4,2-4,4$ & $4,0-4,3$ \\
\hline Összkoleszterin, mmol/l & $3,65-5,44$ & $4,65-7,74$ & $5,67-9,04$ \\
\hline LDL-koleszterin, $\mathrm{mmol} / \mathrm{I}$ & $1,55-3,96$ & $1,99-4,77$ & $2,52-5,80$ \\
\hline HDL-koleszterin, mmol/l & $1,04-2,02$ & $1,35-2,25$ & $1,24-2,25$ \\
\hline Triglicerid, $\mathrm{mmol} / \mathrm{l}$ & $0,5-1,8$ & $0,9-4,3$ & $1,5-5,1$ \\
\hline APO B, mg/dl & $58-81$ & $66-188$ & $85-238$ \\
\hline
\end{tabular}

A munka 1975-2008 között megjelent közlemények metaanalízise. Nem veszi figyelembe az időközben megváltozott módszereket (LDL-koleszterin számolva, illetve közvetlenül mérve stb.). A cukoranyagcsere mutatói közül a $\mathrm{HbA}_{1 c}$-re vonatkozó adatok használhatatlanok - az első két időszakra 4,0-6,0\% közötti adatot és a harmadikra 4,0-7,0\%-ot ad meg a módszerek ismertetése nélkül. C-peptidre, illetve inzulinra vonatkozó adat nem szerepel (Abbassi-Ghanawati és munkatársai metaanalízise alapján. Az adatok hozzáférhetők a www.perinatology.com weboldalon)

\section{2. táblázat. Vércukorértékek terhességben (Hernandez et al. metaanalízise alapján ${ }^{5}$ )}

\begin{tabular}{|c|c|c|c|}
\hline Vércukor, $\mathbf{m m o l} / \mathbf{I}$ & Átlag és SD & Átlag - 1 SD & átlag + 1 SD \\
\hline Éhomi & $3,94 \pm 0,43$ & 3,51 & 6,38 \\
\hline Reggeli után 1 órával & $6,16 \pm 0,70$ & 5,47 & 6,08 \\
\hline Reggeli után 2 órával & $5,53 \pm 0,55$ & 4,98 & 6,63 \\
\hline Ebéd után 1 órával & $5,95 \pm 0,68$ & 5,28 & 6,05 \\
\hline Ebéd után 2 órával & $5,48 \pm 0,58$ & 4,90 & 6,84 \\
\hline Vacsora után 1 órával & $6,05 \pm 0,78$ & 5,27 & 6,13 \\
\hline Vacsora után 2 órával & $5,55 \pm 0,57$ & 4,98 & 5,46 \\
\hline Átlag & $4,90 \pm 0,56$ & 4,35 & \\
\hline
\end{tabular}

Megjegyzés: kb. 200 mérés metaanalízise 12 vizsgálat alapján. A legtöbb adat a terhesség 30. hete utáni időszakra vonatkozik SD: standard deviáció 
(1995-2010 között végzett) vizsgálatban a kontrollcsoportok átlagai 3,04 és $0,81 \mathrm{mmol} / 1 \mathrm{között}$ szórtak! A GDM diagnózisa kizárólag a vércukor értékein alapul, de a referenciatartományok és a kóros állapot határértékei között sincs egyezés. ${ }^{2,3,4,5}$

\section{A cukoranyagcsere szabályozása terhességben}

A terhességben a cukoranyagcsere szabályozását alapvetően ugyanazok a hormonok biztosítják, mint nem-terhes állapotban. A vércukorszint az inzulin és az úgynevezett inzulin-,,antagonisták“ összehangolt együttműködése eredményeként csak minimális mértékben ingadozik. Étkezések között a szervek glukózellátását elsősorban a máj biztosítja a glikogenolízis és a glukoneogenezis segítségével. Étkezéseket követően az inzulin aktiválja az izmok és a zsírszövet glukózfelvételét és az ezt követő, sejten belüli anyagcsere-folyamatokat. A májban fokozódik a glikogén szintézise.

Erre a circadian, étkezésekkel összefüggő rendszerre épül rá a terhességi szabályozás. A terhesség első felére a Langerhans-szigetek béta-sejtjeinek jelentős (1,4-2,4-szeres) hyperplasiája jellemző, amiért elsősorban az agyalapi mirigy és a méhlepény lactogen hormonjai (prolaktin, növekedési hormon, placentaris lactogen stb.) a felelősek. Az ennek következtében megjelenő hyperinsulinaemia a magyarázata az ebben az időszakban előforduló éhomi hypoglykaemiáknak is. A fokozott inzulinszekréció hat a zsírszövetre, és fontos szerepe van az energiatartalékok létrehozásában. Ezt a helyzetet lehet inzulinrezisztenciának tekinteni, de nem szabad figyelmen kívül hagyni azt a tényt, hogy fiziológiás folyamatról van szó, amely nélkül a magzat nem jutna elég tápanyaghoz. (Meg kell jegyezni, hogy az elhízással összefüggő inzulinrezisztenciában nincs béta-sejt-hyperplasia és az inzulinszekréció kompenzatorikus fokozódásának határt szab az endoplasmatikus reticulum sztressz.) Erre az időszakra az anabolikus folyamatok jellemzők. ${ }^{6,7}$ Freinkel és munkatársai a múlt század hetvenes éveiben e folyamatot felgyorsult éhezésnek (accelerated starvation) nevezték. ${ }^{8}$

A terhesség második felére az energiatartalékok felhasználása a jellemző. Ennek egyik következménye, hogy a perifériás szövetek inzulinérzékenysége csökken. Ez a májban több mint 50\%-ot is elérhet, ugyanakkor $30 \%$-kal növekszik a májban termelt glukóz szintézise is. ${ }^{9,10}$ Ez már jelentősebb inzulinrezisztencia, mint az első hetekben, de még mindig a fiziológiás keretek között van. A különbséget úgy is le lehet írni, hogy a terhesség első fele anabolikus, a második pedig katabolikus (3. táblázat). Ennek ellentmond a fent említett szerzők meghatározása, ${ }^{8}$ akik ezt az időszakot „facilitált anabolizmusként" jellemezték. Ha arra gondolunk, hogy ebben az időszakban a terhes anyák jelentős súlytöbbletet halmoznak fel, akkor valóban kérdéses ezt katabolikus fázisnak tekinteni.

\section{A zsíranyagcsere terhességben}

A lipidek anyagcseréje és annak szabályozása sokkal bonyolultabb, mint a szaharidoké. Ennek az az oka, hogy a lipidek oldhatatlanok a vérplazma vizes közegében, és csak lipoprotein formájában vannak jelen a vérben. Nehezíti a kérdés áttekintését, hogy amíg az energiaforgalom szempontjából a glukóz koncentrációja egyszerű és könnyen

\section{3. táblázat. Cukoranyagcsere a terhesség első és második felében}

\begin{tabular}{|c|l|l|}
\hline Terhesség hete & \multicolumn{1}{|c|}{ Szöveti változások } & \multicolumn{1}{c|}{ Biokémiai mutatók } \\
\hline $1-20$. & $\begin{array}{l}\text { - A Langerhans-szigetek béta-sejtjeinek reverzibilis } \\
\text { hyperplasiája } \\
\text { - A méhlepény hormontermelése }\end{array}$ & $\begin{array}{l}\text { - Éhomi vércukor a referenciatartomány alsó szintjén, } \\
\text { olykor hypoglykaemia } \\
\text { - Postprandialis vércukor enyhén emelkedett } \\
\text { - Enyhén emelkedett lipidszintek }\end{array}$ \\
\hline 21-40. & $\begin{array}{l}\text { - Az anyai szövetek, főleg a máj jelentős } \\
\text { inzulinrezisztenciája } \\
\text { - A gyorsan növekedő magzat szöveteinek fokozott } \\
\text { energiaigénye }\end{array}$ & $\begin{array}{l}\text { - Postprandialis hyperglykaemia } \\
\text { - Jelentősen emelkedett lipid (leginkább triglicerid)-szintek } \\
\text { - Emelkedett szabad zsírsavak, ketontestek és aminosavak }\end{array}$ \\
\hline
\end{tabular}


értékelhető adat a gyakorló orvos számára, addig a zsíranyagcsere rutinszerűen mért paraméterei (koleszterinfrakciók, trigliceridek, apoproteinek) bonyolultabb képet mutatnak és keveset árulnak el az energiaháztartás állapotáról. Az energiatermelésbe közvetlenül bekapcsolódó szabad zsírsavak koncentrációjának mérése nem tartozik a rutin meghatározások közé.

A glukóz- és a zsíranyagcsere között az is nagy különbség, hogy a két energiaforrás tartalékai nagymértékben különböznek egymástól. A májban tárolt glikogén éhezéskor néhány óra alatt lebomlik, a zsírszövetben tárolt energia mennyisége viszont több hétre elegendő. A zsíranyagcsere változásai már a terhesség előtt megkezdődnek, erre utal az is, hogy a mérsékelt gynoid típusú túlsúly kedvező hatással van a fertilitásra.

A terhesség során a lipidanyagcsere mutatói sokkal jelentősebb mértékben változnak, mint a glukóz szintje (1. ábra). Nyitott kérdés, hogy a kétszeresére emelkedett szérum LDL-koleszterin- és a háromszorosára növekedett trigliceridszint pusztán élettani adaptációs folyamat, vagy „gestatiós (dys) lipidaemiának" tekinthető. A zsíranyagcsere válto-

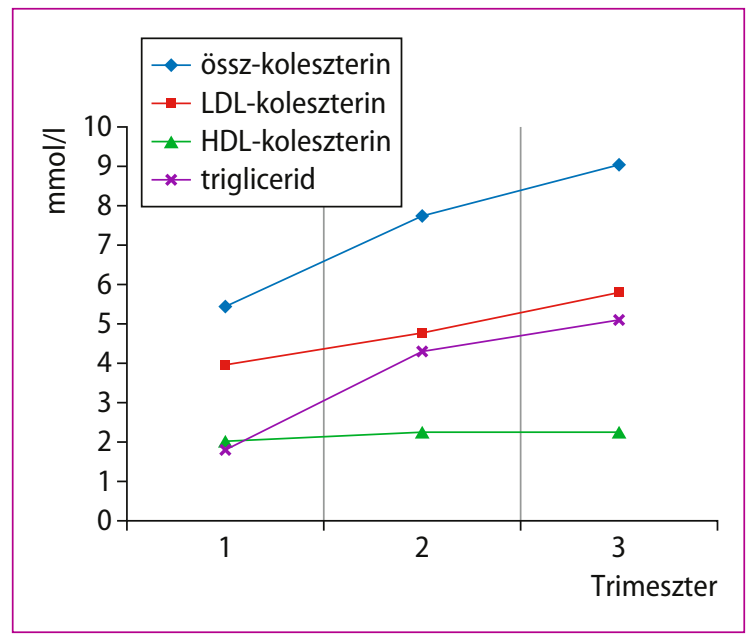

1. ábra. A standard lipidparaméterek változása a terhesség folyamán (Abbassi-Ghanawati és munkatársai adatai alapján ${ }^{2}$ )

Az áttekinthetőség kedvéért csak a referenciaértékek felső határát ábrázoltuk. A legnagyobb, majdnem háromszoros emelkedés a trigliceridek esetében észlelhetö. A HDL-koleszterin szintje a terhesség során nem változik. zásaihoz terhességben a méhlepény lipidtartalma és az ott található lipidek anyagcseréje is hozzájárul. ${ }^{11}$

A változások hátterében többek között a fokozott ösztrogénszekréció áll, ami fokozza a májban a VLDL részecskék szintézisét és csökkenti a hepatikus lipáz aktivitását. A másik fontos tényező a fokozott inzulintermelés és az ezt követő fokozott lipidszintézis. ${ }^{12,13,14,15}$

\section{Az adipokinek szerepe a terhességi anyagcsere szabályozásában}

Az adipokinek a zsírszövet által termelt parakrin, részben endokrin hatású fehérjék. Eredetileg úgy tartották, hogy csak a lipidek anyagcseréjében játszanak szerepet. Ma már nyilvánvaló, hogy más anyagcsere-folyamatokba is bekapcsolódnak, ezek közé tartozik a glukóz metabolizmusa is. ${ }^{16}$

$\mathrm{Az}$ egyik legfontosabb adipokin, amelynek fontos szerepe van a glukózanyagcsere szabályozásában, az adiponektin, amely az Acrp30 (adipocyte complement related protein) fehérjéhez kapcsolódva fejti ki hatását. A placenta már a terhesség kezdeti szakaszában termel adiponektint. ${ }^{17}$

Állatkísérletekben Berg, Combs és Scherer már 2002-ben indirekt összefüggést talált az Acrp30/adiponektin koncentrációja és a vércukorszint között. ${ }^{18}$ Újabb kutatások szerint az adiponektin egyik legfontosabb feladata az izomszövet glukózfelhasználásának aktiválása. ${ }^{19}$

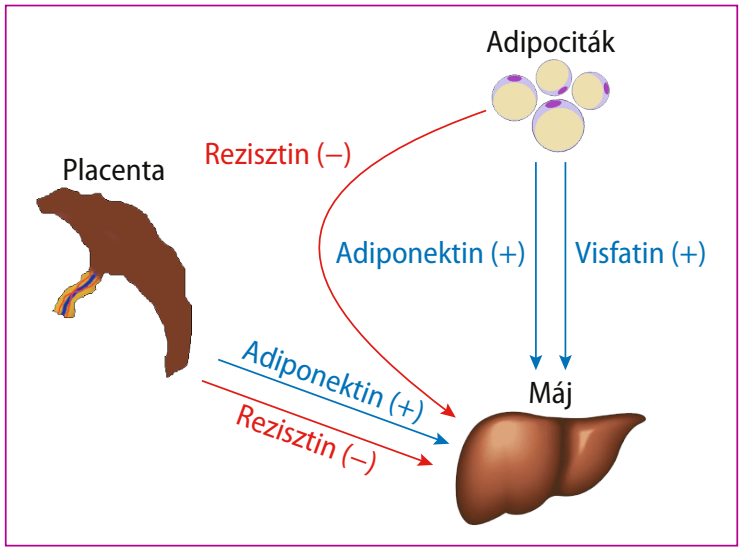

2. ábra. Az adipokinek hatása a szöveti inzulinérzékenységre terhességben 


\section{4. táblázat. A terhességben szerepet játszó adipokinek}

\begin{tabular}{|c|c|c|}
\hline Adipokin név, szerkezet, génlocus & $\begin{array}{c}\text { Szintézis a } \\
\text { placentában }\end{array}$ & Metabolikus funkció \\
\hline Adiponektin/Acrp30, 244 aminosav, 3q7.23 & igen & $\begin{array}{c}\text { Az inzulinérzékenység növelése (protektív tényező GDM kialakulásával } \\
\text { szemben) }\end{array}$ \\
\hline Visfatin, 491 aminosav, 7q22.3 & nem ismert & Szinergikus hatás az adiponektinnel \\
\hline Rezisztin, 108 aminosav, 19p13.2 & igen & Vitatott \\
\hline Leptin, 167 aminosav, 7q32.1 & igen & $\begin{array}{c}\text { Placenta beágyazódása, lipolízis, az inzulinérzékenység csökkentése, } \\
\text { szubklinikus gyulladás indukciója }\end{array}$ \\
\hline Retinolkötő fehérje 4, 182 aminosav, 10q23.33 & nem ismert & Az inzulinérzékenység modulációja \\
\hline SPARC (oszteonektin), 303 aminosav, 5 q31 & nem ismert & Az inzulinérzékenység csökkentése, szubklinikus gyulladás indukciója \\
\hline
\end{tabular}

Terhességben összegeződik a zsírszövet és a placenta által termelt adipokinek hatása. A helyzetet bonyolítja, hogy az adipokinek nem elkülönülve fejtik ki hatásukat, hanem egy komplex hálózat keretében és a „klasszikus" hormonokkal szinergikusan vagy antagonikusan

A leptin elsősorban az étvágy szabályozásában játszott szerepe alapján vált ismertté, de para- és endokrin hatása ennél jóval összetettebb. A terhességben a hypothalamus leptin iránti érzékenysége (és következményesen válaszreakciója) csökken ezt leptinrezisztens állapotnak is lehet tekinteni. A leptinnek ezen felül fontos szerepe van a placenta beágyazódásában, hormontermelésének és a méhlepény anyagcseréjének szabályozásában ${ }^{20,21}$ (2. ábra).

A rezisztinnel kapcsolatos adatok ellentmondásosak. Vérszintje a terhességben növekszik, részt vesz több, placentában képződő enzim termelődésének szabályozásában. Szerepe a GDM, illetve a preeclampsia patogenezisében nem kizárt, de nem is bizonyított. ${ }^{22,23,24}$ Hasonló a helyzet az ugyancsak az adipokinek közé tartozó retinolkötő fehérje (RBP)-4-gyel is. ${ }^{25}$

A visfatin az adiponektinnel együttműködve növeli a szövetek inzulinérzékenységét, és valószínű, hogy feladata a terhességi inzulinrezisztenica élettani határok kötött tartása. ${ }^{26} \mathrm{Az}$ újabban felfedezett adipokinek közül még a SPARC-nak (secreted acidic protein rich in cystein, régebbi nevén osteonectin) lehet szerepe a terhességi glukóz- és zsíranyagcsere szabályozásában. A terhességben jelentős szerepet játszó adipokineket a 4. táblázatban foglaltuk össze.

\section{A gestatiós diabetes}

A GDM definíciója egyértelmű (bár diagnosztikai algoritmusáról vita folyik), patogenezise annál ke- vésbé. A terhesség alatt manifesztálódó (vagy akkor felismert), vércukor-emelkedéssel jellemzett kórkép a terhesek 4-6\%-át érinti, de prevalenciája nagymértékben függ a szűréskor és a diagnosztikában alkalmazott módszerektől és a mért értékek interpretációjától.

Ha a 2008-ban végzett HAPO vizsgálat eredményeiből indulunk ki, amely szerint már 4,2 mmol/l éhomi vércukor körül is fennáll a macrosomia veszélye, akkor a terhesek 18\%-át a veszélyeztettek csoportjába sorolhatjuk. ${ }^{27,28,29}$ A megfelelő szűrés és diagnosztikai módszerek értékelése, valamint a határértékek körül kialakult vita részletezése nem e munka tárgya, de az bizonyos, hogy a kórismézésnek kórélettani alapokra kell épülnie.

A GDM - a többi diabetestípushoz hasonlóan - nem csak a cukoranyagcsere zavara. SchaeferGraf és munkatársai kimutatták, hogy anyagcsere-egyensúlyban lévő GDM-es terhesekben (150 mérés, éhomi, illetve pp. vércukorátlag 4,9, illetve $6,3 \mathrm{mmol} / \mathrm{l})$ az anyai trigliceridek és a szabad zsírsavak koncentrációja a terhesség 28. hetében szoros összefüggést mutatott az újszülöttek születései súlyával és több más antropometriai mutatóval. ${ }^{30}$

A GDM és az adipokinek szekréciója közötti összefüggés vonatkozásában a legtöbb megbízható adat a leptinnel, az adiponektinnel és a visfatinnal kapcsolatos.

$X u$ és munkatársai metaanalízise ${ }^{31}$ alapján kétségtelen tény, hogy a leptin koncentrációja alacsonyabb GDM-ben, mint glukózanyagcsere-zavarral nem társuló terhességben. Ez a csökkent koncentráció kihathat a placenta malinvasiójára is, 


\section{5. táblázat. A terhesség alatt kialakuló/felismert dia- betesformák lehetséges kóroki háttere}

1. A béta-sejt-hyperplasia és a fokozott inzulinszekréció sem képes biztosítani a normális cukoranyagcserét. Okok: Genetikai háttér - paritás - túlsúly - életkor. Valószínúleg ez a leggyakoribb típus, de az is valószínű, hogy etiológiai szempontból nem homogén kórkép.

2. Elmarad a terhességi béta-sejt-hyperplasia és a fokozott inzulinszekréció. A magzat nem kap elég tápanyagot. Hipotetikus példa: inzulinrezisztencia preeclampsiában.

3. A cukoranyagcsere zavara már a terhesség előtt is megvolt, de nem ismerték fel.

4. Egyéb diabetestípus terhesség alatti manifesztációja. Nem gyakori, de lehetséges változat. A monogénes diabetestípusok között gondolni kell például a MODY 2 típus felismerésére.

ami alátámasztja a GDM és a preeclampsia közötti lehetséges összefüggést. ${ }^{32} \mathrm{Az}$ adiponektin és a visfatin szinergikusan hat a túlzott mértékű inzulinrezisztencia ellen, ám e két adipokin koncentrációja csökken GDM-es személyekben. ${ }^{33,34}$ Ezzel szemben a retinolkötő fehérje-4 termelődése az inzulinrezisztencia fokozódásával párhuzamosan növekszik, és bár hatása a glukóz anyagcseréjére nem bizonyított, szerepe lehet a terhességi anyagcserezavarok során kialakuló szubklinikus gyulladásban. ${ }^{35}$ Hasonló a helyzet a SPARC-al kapcsolatban, de ezek az adatok még megerősítésre várnak. ${ }^{36}$

A terhességben megjelenő/kialakuló diabetesformák lehetséges patogenetikai hátterét az 5. táblázatban foglaltuk össze.

\section{Anyagcserezavarok preeclampsiában}

A preeclampsia definíciója nem érinti a cukoranyagcserét. Patogenezisében valószínűleg a trophoblast malinvasiója, valamint immunológiai és genetikai tényezők játszanak szerepet. Ennek ellenére bizonyított tény, hogy a preeclampsia során fokozott az inzulinrezisztencia és jelentős dyslipidaemia jelentkezik, de nem tisztázott, hogy az anyagcserezavarok összefüggenek-e a preeclampsia etiopatogenezisével, vagy annak következményei. A gyakorlatban ez azt jelenti, hogy a két tárgyalt kórkép együttes előfordulása sokkal nagyobb, mint a véletlen egyezés alapján várható lenne. Az összefüggés fordítva is érvényes, egy kis különbséggel - a GDM előfordulása gyakoribb azokban a terhesekben, akiknek a vérnyomása magas. Ennek a jelenleg elfogadott neve „terhességgel asszociált hypertonia“ “. ${ }^{37} \mathrm{Ez}$ azért van, mert a preeclampsia a legtöbb esetben később manifesztálódik, mint a GDM, tehát az epidemiológiai vizsgálatokban a vérnyomás és a cukoranyagcsere zavara között kell kapcsolatot keresni. A két betegség közötti összefüggést az is alátámasztja, hogy a preeclampsia gyakori azokban a terhesekben is, akiknél pregestatiós diabetes (1-es vagy 2 -es típus) van jelen. ${ }^{38}$

Hauth és munkatársai metaanalízise ${ }^{39}$ szerint azoknál, akiknél később megjelent a preeclampsia, kétszer olyan gyakori volt a kóros cukoranyagcsere, mint a nem preeclampsiás csoportnál. A különbség szignifikáns maradt a BMI-re történő korrekció után is. Ebben az analízisben a vizsgált 10154 nullipara közül 1187-nek mérték a glukóz-anyagcsere markereit (éhomi vércukor, inzulin és az ebből számított HOMA-IR és QUCKI érték), amelyek egyértelműen inzulinrezisztenciára utaltak.

\section{Javaslatok a megválaszolatlan kérdések és problémák megoldására}

Az előző fejezetekben vázolt problémák megoldására elsősorban a gyakorló laboratóriumi szakember és a kórélettannal foglalkozók szempontjából próbáltunk meg javaslatokat adni (első három javaslat). A negyedik pont a mindennapi gyakorlatban is megvalósítható. Az ötödikhez a különböző szakterületek (szülészet-nőgyógyászat, pediátria, belgyógyászat) szakembereinek együttműködése szükséges. Mindez azonban csak felületes megközelítés lenne az utolsó előtti pont nélkül, ami az alapkutatásokat illeti. A végső cél természetesen a terhességi anyagcserezavarok megelőzése. A javaslatok:

1. Megbízhatóbb laboratóriumi referenciaértékek meghatározása a fiziológiás terhesség során, beleértve azokat az értékeket (pl. C-peptid) is, amelyek a jelenlegi rendszerben nem szerepelnek.

2. Vizsgálni kell a laboratóriumi értékek öszszefüggését a paritással, a testtömeggel és az anyai életkorral, valamin a magzat fejlődésének mutatóival.

3. Egyeztetés szükséges a referenciaértékek felső tartománya és a már kórjelzőnek tartott értékek között, különös tekintettel a kettő közötti „szürke tartományra”. 
4. Több figyelmet kell szentelni a zsíranyagcsere terhesség alatti változásainak és a megváltozott értékek értelmezésének.

5. Elengedhetetlen a terhességi anyagcserezavarok anyai és magzati következményeinek vizsgálata és analízise.

6. Összehangolt alapkutatás szükséges a terhességi anyagcsere-folyamatok genetikájának, epigenetikájának, proteomikájának stb. feltárására.

7. A kóros állapotok megelőzése és gyógykezelése.
Irodalom

1. Gallos ID, Sivakumar K, Kilby MD Coomarasamy A, Thangaratinam S, Vatish M: Pre-eclampsia is associated with, and preceded by, hypertriglyceridaemia: a meta-analysis. Brit J Obstet Gynecol 2013; 120: 1321-1332. doi:10.1111/1471-0528.12375

2. Abbassi-Ghanavati M, Greer LG, Cunningham FG: Pregnancy and laboratory studies: a reference table for clinicians. Obstet Gynecol 2009; 114: 1326-1331. doi:10.1097/AOG.0b013e3181c2bde8

3. Holt RIG, Coleman MA, MC Cance DR: The implications of the new International Association of Diabetes and Pregnancy Study Groups (IADPSG) diagnostic criteria for gestational diabetes. Diabetic Med 2011; 28: 382-385. doi:10.1111/j.1464-5491.2011.03236.x

4. Aggarwal MM: Gestational diabetes mellitus: an update on the current international diagnostic criteria. World J Diabetes 2015; 6: 782-791. doi:10.4239/wjd.v6.6.782

5. Hernandez TL, Friedman JE, Van Pelt RE Barvour LA: Patterns of glycaemia in normal pregnancy: should the current therapeutic targets be challenged? Diabetes Care 2011; 34: 1660-1668. doi:10.2337/dc11-0241

6. Sorensen RL, Brelje TC: Adaptation of islets of Langerhans to pregnancy: B-cell growth, enhanced insulin secretion and the role of lactogenic hormones. Horm Metab Res 1997; 29: 301-307. doi:10.1055/s-2007-979040

7. Baeyens L, HindiS, Sorenson RL German RS: Beta cell adaptation in pregnancy. Diabetes Obes Metab 2016; 18(Suppl.1): S63-S70. doi:10.1111/dom.12716

8. Freinkel N, Metzger BE, Nitzan M Hare JW, Shambaugh GE, Marshall RT, et al.: "Accelerated starvation" and mechanisms for the conservation of maternal nitrogen during pregnancy. Isr J Med Sci 1972; 8: 426-439.

9. Lain KY, Catalano PM: Metabolic changes in pregnancy. Clin Obstet Gynecol 2007; 50(4): 938-948. doi:10.1097/GRF.0b013e31815a5494

10. Melzer K, Kayser B, Schutz Y: Respiratory quotient evolution during normal pregnancy: What nutritional or clinical information can we get out of it? Eur $J$ Obstet Gynecol Reprod Biol 2014; 176: 5-9. doi:10.1016/j.ejogrb.2014.02.014

11. Brown SHJ, Eather SR, Freeman DJ, Meyer BJ, Mitchell TW: A lipidomic analysis of placenta in preeclampsia: evidence for lipid storage. PLoS One 2016; 11(9): e0163972. doi:10.1371/journal.pone.0163972

12. Emet T, Ustüner I, Güven SG Balik G, Ural UM, Tekin YB, et al.: Plasma lipids and lipoproteins during pregnancy and related pregnancy outcomes. Arch Gynecol Obstet 2013; 288: 49-55. doi:10.1007/s00404-013-2750-y

13. Charlton F, Toother J, Rye KA: Cardiovascular risk, lipids and pregnancy: Preeclampsia and the risk of later life cardiovascular disease (Review). Heart Lung Circ 2014; 23: 203-212. doi:10.1016/j.hlc.2013.10.087

14. Timalsina S, Gyawali P, Bhattarai A. Comparison of lipid profile parameters and oxidized low-density lipoprotein between normal and preeclamptic pregnancies in a tertiary care hospital in Nepal. Int J Women's Health 2016; 8: 627-631. doi:10.2147/IJWH.S117850

15. El Khouly NI, Sanad ZF, Saleh SA, Shabana AA, Elhalaby AF, Badre EE: Value of first-trimester serum lipid profile in early prediction of preeclampsia and its severity: a prospective cohort study. Hypertens Pregnancy 2016; 35: 73-81. doi:10.3109/10641955.2015.1115060

16. Trayhurn P,Wood SI: Adipokines: inflammation and the pleiotropic role of white adipose tissue. Br J Nutr 2004; 92(3): 347-355. doi:10.1079/BJN20041213

17. Caminos JE, Nogueiras R, Gallego R Pineda R, Gonzalez CR, Barreiro $M L$, et al.: Expression and regulation of adiponectin and receptor in human and rat placenta. J Clin Endocrinol Metab 2005; 90: 4276-4286. doi:10.1210/jc.2004-0930

18. Catalano PM, Hoegh M, Minium J, Huston-Presley L, Bernard S, Kalhan $S$, et al.: Adiponectin in human pregnancy: implications for regulation of glucose and lipid metabolism. Diabetologia 2006; 49: 1677-1685. doi:10.1007/s00125-006-0264-x 
19. Berg AH, Combs TP, Scherer PE: ACRP 30/adiponectin: an adipokine regulating glucose and lipid metabolism. Trends Endocrinol Metab 2002; 13(2): 84-89. doi:10.1016/S1043-2760(01)00524-0

20. Lacroix M, Battista MC, Doyon M, Moreauu J, Patenaude J, Guillemette L., et al: Higher maternal leptin levels at second trimester are associated with subsequent greater gestational weight gain in late pregnancy. BMC Pregnancy and Childbirth 2016; 16: 62. doi:10.1186/s12884-016-0842-y

21. Miehle K, Stepan H, Fasshauer M: Leptin, adiponectin and other adipokines in gestational diabetes mellitus and pre-eclampsia. Clin Endocrinol 2012; 76 : 2-11. doi:10.1111/j.1365-2265.2011.04234.x

22. Haluzik $M$, Haluzik $D$ : The role of resistin in obesity-induced insulin resistance. Curr Opin Investig Drugs 2006; 7(4): 306-311.

23. Skvarca A, Tomazic M, Krhin B, Blagus R, Janez A: Adipocytokines and insulin resistance across various degrees of glucose tolerance in pregnancy. J Int Med Res 2012; 40: 583-589. doi:10.1177/147323001204000220

24. Huang $\mathrm{LL}$, Xiong J, Purvarshic G, Wang SM, Zhong $\mathrm{LL}$, Tang $\mathrm{H}$ : Lipid changes and effect of diet therapy only in gestational diabetes mellitus and normal pregnancy in developing area southern China. J Food Nutr Res 2014; 2: 335-339. doi:10.12691/jfnr-2-7-1

25. Khovidhunkit W, Pruksakorn P, Plengpanich W, Tharavanij T:: Retinol-binding protein 4 is not associated with insulin resistance in pregnancy. Metabolism 2012; 61: 65-69. doi:10.1016/j.metabol.2011.05.019

26. Park S, Kim MY, Baik SH, Woo JT, Kwon YJ, Daily JW, et al.: Gestational diabetes is associated with high energy and saturated fat intakes and with low plasma visfatin and adiponectin levels independent of prepregnancy BMI. Eur J Clin Nutr 2013; 67: 196-201. doi:10.1038/ejcn.2012.207

27. Mether BE (corresponding author) International Association of Diabetes and Pregnancy Study Groups recommendations on the diagnosis and classification of hyperglycemia in pregnancy. Diabetes Care 2010; 33: 676-682. doi:10.2337/dc09-1848

28. Lindsay RS: Maternal glycaemia and neonatal adiposity: new insights from the hyperglycaemia and adverse pregnancy outcomes (HAPO) study. Diabetes 2009; 58: 302-303. doi:10.2337/db08-1562

29. Moses RG: New consensus criteria for GDM. Problem solved or a Pandora's box? Diabetes Care 2010; 33: 690-691. doi:10.2337/dc09-2306

30. Schaefer-Graf UM, Graf K, Kulbacka I, Kjos SL, Dudenhausen J, Vetter K, et al: Maternal lipids as strong determinants of fetal environment and growth in pregnancies with gestational diabetes mellitus. Diabetes Care 2008; 31 : 1858-1863. doi: $10.2337 / \mathrm{dc} 08-0039$

31. XU J, Zhao YH, Chen YP, Yuan XL, Wang J, Zhu H, et al.: Maternal circulating concentrations of tumor necrosis factor-alpha, leptin, and adiponectin in gestational diabetes mellitus: a systematic review and meta-analysis. Sci World J 2014; 2014: 926932 doi:10.1155/2014/926932.

32. Saini V, Kataria M, Yadav A, Jain A: Role of leptin and adiponectin in gestational diabetes mellitus: a study in a North Indian tertiary care hospital. Internet J Med Update 2015; 10(1), 11-14. doi:10.4314/ijmu.v10i1.3

33. Vitoratos N, Deliveliotou E, Vlahos NF, Mastorakos G, Papadias K, Botsis D, Creatsas GK: Serum adiponectin during pregnancy and pospartum in women with gestational diabetes and normal controls. Gynecol Endocrin 2008; 24: 614-619. doi:10.1080/09513590802342866

34. Rezvan N, Hosseinzadeh-Attar JM, Masoudkabir F, Moini A, Janani L, Mazaherioun M: Serum visfatin concentrations in gestational diabetes mellitus and normal pregnancy. Arch Gynecol 0bstet 2012; 285: 1257-1262. doi:10.1007/s00404-011-2156-7

35. Saucedo R, Zarate A, Basurto L, Hernandez M, Puello E, Galvan R, et al.: Relationship between circulating adipokines and insulin resistance during pregnancy and postpartum in women with gestational diabetes. Arch Med Res 2011; 42: 318-323. doi:10.1016/j.arcmed.2011.06.009
36. Xu L, Ping F, Yin J, Xiao X, Xiang H, Ballantyne CM, et al.: Elevated plasma SPARC levels are associated with insulin resistance, dyslipidemia, and inflammation in gestational diabetes mellitus. PLoS One 2013; 8: e81615. doi:10.1371/journal.pone.0081615.

37. Mastrogiannis DS, Spiliopoulos M, Mulla W, Homko CJ: Insulin resistance: The possible link between gestational diabetes and hypertensive disorders of pregnancy. Curr Diab Rep 2009; 9: 296-302. doi:10.1007/s11892-009-0046-1

38. Weisgerber TL, Mudd LM: Preeclampsia and diabetes. Curr Diab Rep 2015; 15. doi:10.1007/s11892-015-0579-4

39. Hauth JC, Clifton RG, Roberts JM, Myatt L, Spong CY, Leveno KJ, et al:: Maternal insulin resistance and preeclampsia. Am J Obstet Gynecol 2011; 204: 327.e1-e6. doi:10.1016/j.ajog.2011.02.024

\section{A szerzö levelezési címe:}

\section{Dr. Rácz Olivér}

Vojenská 8, SK 04001 Kosice, Szlovákia

E-mail: olliracz@gmail.com 